\title{
P. C. Chang's Concept of Human Dignity for the Universal Declaration of Human Rights"
}

\section{Pinghua Sun ${ }^{* *}$}

In the early days of the UN, human rights was one of the most pressing issues. After the UN Commission on Human Rights was established, the international community began to draft the UDHR. By exploring UN archives, this paper finds that during that process, Pengchun Chang (P. C. Chang), the Chinese representative, drew heavily on his view that human dignity was the raison d'etre of human rights, and as a consequence recognition of the importance of human dignity was a key element in the UDHR eventually adopted. I conclude that Chang was skilled in his advocacy of the recognition of human dignity as he persuaded people to reach a consensus on human rights standards, providing a common standard for all peoples and all nations. This paper will mainly ask: What was the role of human dignity in P. C. Chang's idea on human rights? What role can we say human dignity played? How did the UDHR treat the issue of human dignity?

\section{Keywords}

Human Dignity, Human Rights, P. C. Chang, UDHR, Traditional Chinese Culture

* The earlier version of this article was presented at Christ Church College, Oxford on August 3, 2018.

** Professor at China University of Political Science and Law. MA (Warwick), Ph.D. (CUPL). ORCID: https://orcid. org/0000-0002-1470-9542. Much gratitude is extended to John Nicholson, a senior copy editor with CHINA DAILY, for his careful revision, insightful comments and warm-hearted assistance in the proofreading. The author may be contacted at: fadaphsun@aliyun.com/Address: China University of Political Science and Law, 25, Xitucheng Road, Haidian District, Beijing 100088 P. R. China. 


\section{Introduction}

For the past eight years I have devoted much time to human rights studies. The following four books are main publications of my research: 1) THE STUDY OF THE Universal Declaration of Human Rights [<世界人权宣言>研究] (Peking University Press 2012); 2) Human Rights Protection System in China (Springer 2014); 3) Pengchun Chang: A Crucial Architect of the International Human Rights System [张彭春: 世 界人权体系的重要设计师] (Social Sciences Academic Press 2017); and 4) Historic Achievement of a Common Standard: Pengchun Chang and the Universal Declaration of Human Rights (Springer 2018). These works have attracted scholars' attention in human rights fields both in China and abroad. In August 2018 I was invited to attend a conference in Oxford on human dignity for everyone everywhere: founding figures, foundations and the uses of human dignity. At the conference I delivered a keynote speech titled "The role of human dignity in P. C. Chang's thought about human rights." "1

However, as soon as I had reviewed the contents of that speech and the aforementioned works a question occurred to me: What was the role of human dignity in P. C. Chang's idea on human rights? This research will try to answer this fundamental question. It will be further subdivided into the following questions: 1) Who was P. C. Chang?; 2) What concept did he have of human rights?; 3) Based on the UN documents, what role can we say human dignity played in his concept of human rights?; and 4) How did the Universal Declaration of Human Rights 1948 ("UDHR") treat the issue of human dignity?

\section{Who is Pengchun Chang?}

Pengchun Chang (P. C. Chang) (1892-1957), whose style name was Zhòngshù [仲述], was born in Tianjin on April 22, 1892. He was an internationally renowned educator, philosopher, playwright, diplomat, human rights activist and the main drafter of the $\mathrm{UDHR}^{2}$

1 See Human Dignity for Everyone Everywhere: Founding Figures, Foundations, and the Uses of Human Dignity, available at https:/www.iclrs.org/content/blurb/files/Oxford\%20HD\%20Conference.Schedule.2018.07.31.pdf (last visited on Apr. 26, 2019).

2 Pinghua Sun, Peng-Chun Chang: A world-renowned human rights activist. 6 Hum. RTs. 40-5 (2011). 
With a Western education, Chang was one of Professor John Dewey's favorite students at Columbia University and was awarded a doctorate in philosophy (1924) there. He was also a planner of Nankai University as an acting principal (1917-19) and a contributor as the first Dean of Teaching Affairs at Tsinghua University (192326). He taught at Tsinghua (1923-26), Nankai University (1926-37), the University of Chicago (1931), the Art Institute of Chicago (1931), the University of Hawaii (193334) and Columbia University (1945). "Despite his experience in the West, Chang remained intellectually committed to the values learned from Asian culture, tradition, and philosophy."3

He was also a renowned educator of drama and a director, and the mentor to the renowned playwright Cao Yu. He was invited to be a director for Mei Lanfang's tour performance both in the US (1930) and in Russia (1935), spreading traditional Chinese culture and participating in civil diplomatic activities. He edited the play New Village Head, which has been considered one of the "iconic works of modern Chinese dramas." He led the way in modernizing Chinese drama in the first half of the 20th century, promoted its internationalization and founded the director system in China.

Nourished by a multitude of cultures, especially traditional Chinese culture, Chang's philosophy of pluralism played an important role in the construction of the international human rights system. He was also an excellent diplomat and was the minister to Turkey (1940-42) and ambassador to Chile (1942-45). When the first conference of the UN General Assembly was held in London from January 10 to February 14, 1946, Chang attended there as one of China's four official representatives. ${ }^{5}$ During the conference, he was appointed Resident Chief Delegate (with ambassadorial rank) to the UN Economic and Social Council (1946-52).

From 1947 to 1948, he served as vice chairman of the UN Commission on Human Rights and vice chairman of the drafting committee, making outstanding contributions in the drafting of the UDHR and "headed the Chinese delegation to the 1948 Geneva conference on freedom of information." ${ }^{\prime 6}$ The UN official website appraises Mr. P. C. Chang as follows:

He was able to explain the Chinese concepts of human rights to the other delegates and

3 See Chang, Peng-Chun, available at http://ccnmtl.columbia.edu/projects/mmt/udhr/biographies/217.html (last visited on Apr. 15, 2019).

4 Guoliang Cui, Postscript [后记], in On Education and Dramatic Arts by Pengchun Chang [张彭春论教育与戏剧艺 术] 712 (Guoliang Cui \& Hong Cui eds., Nankai University Press, 2004).

5 The other three official representatives of China to the UN were Dr. V. K. Wellington Koo (Gu Weijun), Dr. Pingsheung Foo (Bingchang Fu) \& Dr. Chien-Tai (Qian Tai).

6 See Peng Chun Chang, Diplomat, 65, Dies, N.Y. Times, July 21, 1957. 
creatively resolved many stalemates in the negotiation process by employing aspects of Confucian doctrine to reach compromises between conflicting ideological factions. He insisted, in the name of universalism, on the removal of all allusions to nature and God from the Universal Declaration of Human Rights. ${ }^{7}$

Chang retired from the UN in 1952 and died of a heart attack at the age of 65 in New Jersey on July 19, 1957.

\section{Chang's Concept of Human Rights}

Chang made outstanding contributions to international protection of human rights. What form did those contributions take, then? To explore this question, I shall discuss his concept of human rights, namely "Pengchun Chang's Pluralism on Human Rights" from the following four points of view: theoretical foundation, social foundation, rich connotations, and contemporary evaluation. ${ }^{8}$ In particular, after giving a brief introduction to his concept of human rights, I shall focus on the rich connotative meaning of Chang's pluralism on human rights.

\section{A. Introduction to Chang's Concept of Human Rights ${ }^{9}$}

As a world-renowned human rights activist, Chang was engaged in both civic activities and public diplomacy. He also helped draft the Universal Declaration of Human Rights ("UDHR”). Before drafting the UDHR, however, Chang had never touched on the question of human rights from an international legal aspect. Neither had he published articles or works relevant to human rights. In the legal circles in China, few people have appreciated his contribution on the field of human rights. More attention is rather paid to his rich activities for education and the dramatic arts. However, his great contribution to the international protection of human rights was not accidental. His rich life experience equipped him with a profound appreciation of human hardship and helped shape his deep thinking on human nature and the ground of protecting human rights. Those laid a solid foundation for the formation of

7 Pinghua Sun, Historic Achievement of a Common Standard: Pengchun Chang and the Universal Declaration of Human Rights 411 (2018).

8 Pinghua Sun, Pengchun Chang: A cructal architect of the international human Rights System [张彭春: 世界人权 体系的重要设计师] 333-87 (Social Sciences Academic Press, 2017).

9 Id. at 291-2. 
his multilateral perspectives on human rights.

Chang could either view things from a philosophical perspective, or stride over the divisions of different schools. He preferred the common interests of mankind to restricting himself to a particular nation or society. With a broad-minded, downto-earth attitude and great attention to human nature, he defined all problems including the human rights question beyond differences of politics, cultures, races and philosophies. He finally built up a pluralistic philosophical view on human rights. His idea on human rights laid a solid foundation for constructing the postwar international human rights protection system later. He played a decisive role in drafting the UDHR in the end.

\section{B. Rich Connotative Meaning of Chang's Concept of Human Rights}

After being nourished by traditional Chinese culture, Chang fought hard in the pursuit of saving the nation through education. After being immersed in Western philosophy, he also understood the Western world and Islamic culture by public diplomacy from 1940 to 1945. During that time, Chang accumulated his profound experience of the fundamental concept of Latin American human rights. His footprints could be found all over the globe, from east to west and north to south; his insightful worldviews were further deepened and diversified. As a human rights philosopher, his deep understanding about the world and its multi-cultures was often being expanded. His "reading tens of thousands of books and traveling tens of thousands of miles" meant that his in-depth knowledge came not just from the pages of books, but from rich social experience. ${ }^{10}$ In this course, his accomplishments as an educator were nourished; his feelings as a dramatic artist strengthened; and his skills as a diplomat sharpened. While disseminating Chinese culture worldwide, his recognize global cultures more deeply by comparisons. This was a fundamental of pluralistic philosophy of human rights.

Chang's core ideology of human rights is 'humanism.' He cherished the value of human dignity. He was Confucian and patriot. He devoted himself to disseminating the profound traditional Chinese culture worldwide. Chang specially adhered to Dewey's pragmatism. His materialism ran counter to metaphysical philosophy. His collectivism reminded him of keeping the whole world in mind and attaching importance to equality. His optimism encouraged him to fight while facing difficulties. Just as John Humphrey commented on Chang in his memoirs: "He was a master of the art of compromise and, under cover of a quotation from Confucius,

10 Sun, supra note 8 , at 368. 
would often provide the formula which made it possible for the Commission to escape from some impasse."11 Chang's pluralistic philosophy of human rights may be summarized as follows:

1. Adhering to the people-oriented principle and carrying forward the spirit of humanism;

2. Praising traditional Chinese culture and advocating Chinese civilization and wisdom;

3. Upholding Confucian philosophy and abandoning Western centralism;

4. Restricting 'reason' by 'conscience' on the basis of equality and freedom;

5. Advocating the universality of human rights and respecting pluralism;

6. Emphasizing reciprocal equivalence of rights and obligations and paying attention to collective human rights;

7. Insisting on the philosophy of pragmatism and paying attention to economic, social and cultural rights; and

8. Advocating the implementation of human rights education and promoting the protection of national human rights. ${ }^{12}$

\section{Human Dignity in Chang's Concept of Human Rights}

The preamble to the United Nations Charter declares the determination of mankind "to reaffirm faith in fundamental human rights, in the dignity and worth of the human person, in the equal rights of men and women." The UDHR states in its preamble that "recognition of the inherent dignity and of the equal and inalienable rights of all members of the human family is the foundation of freedom, justice and peace in the world." It also declares in Article 1 that "all human beings are born free and equal in dignity and rights." Moreover, both the International Covenant on Economic, Social and Cultural Rights (1966) and the International Covenant on Civil and Political Rights (1966) proclaim in their preambles that human rights "derive from the inherent dignity of the human person." The Vienna Declaration and Programme of Action (1993) also says in its preamble that "all human rights derive from the dignity and worth inherent in the human person." As a major founding figure of the UDHR, Chang valued human dignity, having learned from the painful lessons of World War II. He frequently mentioned human dignity, viewing it as the

11 J. Humphrey, The memoirs of John Humphrey, the first Director of the United Nations Division of Human Rights, 5 Hum. Rts. Q. 387-439 (1983). See also J. Humphrey, Human Rights and the United Nations: A great adventure 23 (1984)

12 Sun, supra note 8 , at 303 . 
source and foundation of human rights, as well as the purpose of protecting human rights. ${ }^{13}$ Let's now take a look at Chang's concept of human dignity.

\section{A. The Human Dignity Cherished by the UDHR's Founding Figures}

The founding figures of the UDHR shared a common understanding of the role of human dignity. Eleanor Roosevelt (1884-1962) was the US representative to the UN. She was chairman of the Commission on Human Rights (1946-52), in charge of the drafting work of the International Bill of Rights. Though she was not an expert on human rights law, her outstanding contribution to the drafting process of the declaration was lauded throughout the world. ${ }^{14}$ Her enthusiasm for work at the UN was rooted in her humanitarian convictions and her steady faith in human dignity and worth. She once said: "The 'word' dignity', regarding which there was some question in the Committee, had also been considered at great length; the Commission had decided to include it in order to emphasize the inherent dignity of all mankind., ${ }^{, 15}$

René Cassin, French representative to the United Nations Conference on International Organization in the drafting of the UN Charter, insisted that respect for human rights and dignity explicitly be set out in the Charter. ${ }^{16}$ Cassin has been called the father of the UDHR for his contribution to drafting the UDHR." "It was in that capacity that he was honored with the Nobel Peace Prize in 1968." 18 Personally, twenty-six of Cassin's relatives lost their lives in Germany under the Nazi regime, so he had an extremely acute sense of human dignity.

Chang came to the drafting process with few academic achievements in the human rights field, but he fully experienced many other aspects of human rights as a philosopher, educator, diplomat and artist. In addition, during the Japanese invasion, he nursed deep emotional wounds as a result of the bombing of Nankai University. This horrible experience gave him a profound understanding of human dignity. In drafting the UDHR, his method was to seek a foundation for human rights grounded

13 U.N. Doc. E/PV.6, at 41-2, available at https://undocs.org/E/PV.6 or http://www.un.org/en/ga/search/view_doc. asp?symbol=E/PV.6 (last visited on May 16, 2019). See also Table 1.

14 M. Glendon, A World Made New: Eleanor Roosevelt and the Universal Declaration of Human Rights 206 (2001).

15 U.N. Doc. A/C.3/SR.98, at 110, available at https://undocs.org/A/C.3/SR.98 (last visited on May 16, 2019).

16 Pinghua Sun, The Study of Universal Declaration of Human Rights [<世界人权宣言〉研究] 58 (Peking University Press 2012). See also Sun, supra note 8, at 7.

17 M. Agi, René Cassin, Prix Nobel de La Paix, 1887-1976: père de la Dèclaration universelle des droits de L'homme (1998).

18 J. Winter \& A. Prost, René Cassin and Human Rights: From the Great War to the Universal Declaration 237 (2013). 
in human dignity, which "paved the way for the arrival of the era of universal human rights." ${ }^{, 19}$ Other founding figures, Charles Malik, ${ }^{20}$ John Humphrey ${ }^{21}$ had a similar understanding of the role of human dignity.

\section{B. Influential Factors in Chang's Concept of Human Dignity}

With his humanism, Chang cherished the value of human dignity. Human rights emanate from human dignity. Chang also associated Rousseau's understanding of human nature with Mencius idea that the kindness in humans that drives them to care for others rather than being preoccupied with themselves is the main defining difference between humankind and lower animals. Apart from kindness, reason and conscience, Chang's concept of human dignity was influenced by: 1) Human dignity in traditional Chinese culture; ${ }^{22}$ and 2 ) his painful experiences.

\section{Traditional Chinese Culture}

In traditional Chinese culture, although the words 'human rights' were not clearly enunciated, Confucianism, as an outstanding representative of traditional Chinese culture, includes a rich strain of human rights concepts. Confucian philosophy lays an emphasis on people's dignity, from which human rights originate. The Master said: "The commander of the army may be carried off, but the will of the common man cannot be made to change." ${ }^{23}$ Confucius valued an individual's willingness regardless of his social status. When Confucius was asked if there was a single precept that could guide a man throughout his life, he answered: "What you do not wish done to yourself do not do to others." 24 This has become a golden rule for human beings of

19 Chengwei Ju, On the contribution of Confucianism to the new human rights theory: Starting from Peng Chun Chang's contributions to the formulation of the Universal Declaration of Human Rights, 4 CHINA LEGAL SCI. 51-68 (2016).

20 H. Malik (ed.), The Challenge of Human Rights: Charles Malik and the Universal Declaration (2000).

21 A. Hobbins (ed.), On the Edge of Greatness: The Diaries of John Humphrey, First Director of the United Nations Division of Human Rights 1948-1949, 1 (1994).

22 The Analects of Confucius [论语] (Shandong University Press, 1991). (Tianchen Li et al. trans. into English). (There are many Confucian doctrines relevant to benevolence, rites, morality and harmony in The Analects of Confucius. Here are some examples: The Master said: “Filial piety and fraternal love are certainly the roots of benevolence.” [子曰: “孝弟也 者, 其为仁之本与!’] The Master said: “Clever talk and a pretentious manner have little to do with benevolence.”[子曰: “巧 言令色，鲜矣仁!”] The Master said: “In carrying out the rites it is harmony that is prized.” [子曰: “礼之用, 和为贵。”] The Master said: “A man without charity in his heart—what has he to do with rites?” [子曰: “人而不仁, 如何礼?”] The Master said: “A man of morality will never live in solitude; he will always bring companions.”[子曰: “德不孤, 必有邻.”])

23 The Analects of Confucius (Book IX: Rarely Did the Master) [论语] 119 (Shandong University Press, 1991) (Tianchen Li et al. trans. into English). [子曰: “三军可以夺帅也, 匹夫不可夺志也。”]

24 The Analects of Confucius (Book XII: Yan Yuan) [论语] 174 (Shandong University Press, 1991). (Tianchen Li et al. trans. into English). [子曰: “己所不欲, 勿施于人。”] See also Pinghua Sun, Human Rights Protection System IN CHINA 5 (2014). 
the modern and civilized world. With regard to government, Mencius thought that "the people are the most important element in the nation; the spirits of land and grain are the next; the sovereign is the lightest." ${ }^{25}$

The drafting course of the UDHR illustrated how Confucianism and human rights ideas in traditional Chinese culture became the historical origins of the UDHR. ${ }^{26}$ Chang stressed the importance of not overlooking human dignity, the principle of equality, the universality for application and the drafting background of the UDHR on the basis of China's traditional philosophy, especially Confucianism. ${ }^{27}$ During the discussion, he insisted on pluralism, emphasizing the dignity of people, advocating the universality of human rights and keeping equality and non-discrimination as a basic principle. ${ }^{28}$

\section{His Painful Experiences}

After the Marco Polo Bridge Incident in 1937, the Japanese army bombarded Nankai University, which was almost razed to the ground. The university, founded by his elder brother Boling Chang ${ }^{29}$ and run with painstaking effort together with him, was then occupied by the Japanese. Helplessly, a disguised Chang left Tianjin by night on a boat. He originally planned to travel directly to Shanghai and then to Nanjing, but he learned that the Japanese had blocked sea routes. So he had to flee overland from Weihai to Nanjing. ${ }^{30}$

He should thus experience firsthand the brutality and inhumanity of Japanese militarism in China, something that would abide with him for the rest of his life. Then, the Japanese brutality fueled his patriotism. The commitment he had to his career in civil diplomacy and to undertaking anti-Japanese propaganda was also reinforced. The importance of giving full recognition to the primordial role of human dignity and protecting human rights became clear to him.

Human rights originate from human dignity of an individual who has reason and conscience. It was by Chang's efforts that the concept of 'benevolence' or 'rén' [仁] in Chinese was successfully integrated into the UDHR, which is the common standard

25 The Works of Mencius (pt. 2: ch. 14, Tsin Sin) [孟子] 359 (J. Legge trans. into English, 2014).

26 Sun, supra note 8, at 291.

27 U.N. Doc. A/C.3/SR96, at 98, available at https://undocs.org/A/C.3/SR.96; U.N. Doc. A/C.3/SR103, at 154, available at https://undocs.org/A/C.3/SR.103 (all last visited on May 16, 2019). See also U.N. Doc. E/CN.4/AC.1/SR.8, at 2; UN Doc. E/CN.4/AC.1/SR2, at 2.

28 Id.

29 F. Botton, Zhang Boling: Educator and patriot, in Studies on Asia ANd Africa from Latin America 9-24 (D. Lorenzen ed., 1990).

30 H. Ruth \& Sze-Chun Cheng (eds.), Peng Chun Chang 1892-1957: Biography \& Collected Works 33 (1995). 
for all nations and all people. ${ }^{31}$ The core concept of Confucianism was regarded as the essential attribute of human beings. ${ }^{32}$ It has become the philosophical underpinning for fundamental freedoms in the UDHR. It was of great significance because it imbued the UDHR with concepts of human rights alien to the West, enhancing the universality of the Declaration.

\section{Uses of Human Dignity in Chang's Concept of Human Rights}

At the San Francisco Conference in 1945, representatives of 46 countries discussed the content of the Charter in a spirit of enmity to war and respect for human dignity and values. However, it was unlikely that their work could help to realize specific protection for human dignity and values that people expected. At the conference, governments were legally endowed with the responsibilities to respect inalienable human rights, which were said to belong to everyone regardless of race, color, sex, language, religion, political or other opinion, national or social origin, property, birth or other status. $^{33}$

When drafting the UDHR, many representatives emphasized the importance of the declaration. For instance, the US representative said that inspired by the sincere desire for peace, the Declaration relied on a belief that "man must have freedom in order to develop his personality to the full and have his dignity respected."34 The Canadian representative said the Declaration, inspired by the highest ideals, expressed the most noble principles and aspirations. Chang stressed the importance of remembering the drafting background, human dignity, equality and the principles of universal application of the Declaration, taking traditional Chinese philosophy, especially Confucianism as the basis. For instance, based on traditional Chinese philosophy, Chang declared at the 91st meeting of the Third Committee:

Stress should be laid upon the human aspect of human rights. A human being had to be constantly conscious of other men, in whose society he lived. A lengthy process of education was required before men and women realized the full value and obligations

31 T. Lindholm, Article 1, in The Universal Declaration of Human Rights: A common standard of achievement 4173 (G. Alfredsson \& A. Eide eds., 1999). (Chang mentioned 'rén' by using the term "two-man-mindedness" and gave further explanation by using 'sympathy' or “consciousness of his fellow men.”) See also U.N. Doc. E/CN.4/AC.1/SR.8, at 2 .

32 The Analects of Confucius, supra note 22, at 1-2, 4, 25, 41-44, 55-57, 63-65, 74, 82-84, 86, 89, 93-94, 101-102,104, 107-108, 112-113, 134, 174-175, 185-186, 188-190, 199, 203-204, 211-214, 220-221, 227-228, 243-244, 249, 253$255,260,262,276-279,284,286-288,292 \& 319-323$.

33 UDHR art. 2.

34 Y.B.U.N. (1948-49) 530 (1950). 
of the rights granted to them in the declaration; it was only when that stage had been achieved that those rights could be realized in practice. ${ }^{35}$

During their discussions, he advocated pluralism, emphasizing the advancement of human dignity and elevating the universality of human rights. Based on principles of equality and non-discrimination, he regarded the spirit of tolerance and cooperation, the relationship of rights and obligations, living in harmony, free development of man, as the key elements in his arguments. Chang once pointed out: "A declaration of human rights should be brief and readily understandable by all. It should be a document for all men everywhere, not merely for lawyers and scholars. ${ }^{\prime 36}$ On another occasion, he stressed:

It was only after mature consideration that the Commission on Human Rights had decided to state the principles of equality and liberty in two separate articles of the draft declaration of human rights, which it was submitting to the General Assembly. Article 2 did, in fact, aim at ensuring that everyone, without distinction of any kind, should enjoy all the rights and freedoms set forth in the declaration. Article 6 aimed at translating that principle into a practical reality by granting everyone protection of the law against discrimination in violation of that declaration. The Chinese delegation was in whole-hearted agreement with the Commission on Human Rights and hoped that the Third Committee would make a point of retaining article 2 in its existing form. ${ }^{37}$

Chang said reasoning and conscience are the basic characteristics that distinguish human beings from lower animals. Conscience is the Confucian moral principle and core idea of rén [仁], that is, benevolence, which has become a moral foundation for all mankind.

\section{Chang Valued Human Dignity before Drafting the UDHR}

Chang travelled widely for international support, speaking resolutely in favor of justice. He believed that they should fight to defend freedom and the dignity of human beings. This was the embodiment of his humanistic spirit. For instance, as minister to Turkey, Chang delivered two important speeches to the Royal House of Faisal II and Baghdad College students in Baghdad, Iraq, in March 1942. Chang's speech on a common outlook gives us the following associations. First, Chang

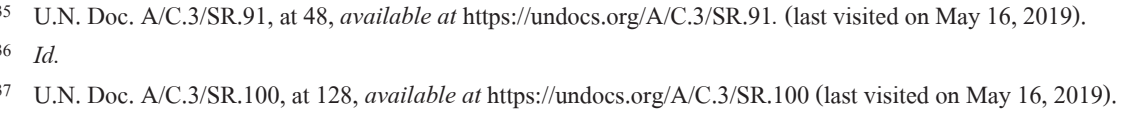


entertained a strong sense of justice, an attitude of optimism and a firm confidence in ultimate victory. Second, China's war against Japanese aggression was for all mankind in safeguarding its dignity and liberty, which brought pride to whoever joined it. Third, it was true that wars were sure to result in deaths. Yet, only after those sufferings could human beings reach the highest level. ${ }^{38}$

In a speech, he regarded China's war against Japanese aggression as a fight of mind and body to safeguard human freedom and dignity against inhumane aggression. He said:

It is through suffering and sacrifice that human beings attain their supreme stature. Motivated and sustained as we are by a profoundly righteous cause, victory is destined to be ours in war as well as in peace. ${ }^{39}$... We feel proud and enthused to take part in this war - a war for the freedom and the dignity of man. ${ }^{40} \ldots$ We fight against the wanton inhumanity of aggressors. ... We fight for independence and for the betterment of living under freedom. ${ }^{41}$

In this UN, he publicly espoused 'human dignity' at the sixth meeting of the second session of the UN Economic and Social Council on May 31, 1946. According to the UN document, Chang pointed out:

Human rights were too large a concept for one commission and that all other organs of the United Nations were concerned with carrying out this concept. He recalled the development of human rights during the last one hundred and fifty years and felt that there existed now a new humanism, as otherwise there would be no incentive for the efforts that were made. Those incentives must be ideals of human freedom and human dignity. ${ }^{42}$

\section{Human Dignity in Chang's Concept While Drafting the UDHR}

Chang, as vice chairman, frequently used the term 'human dignity' in the course of drafting the UDHR.

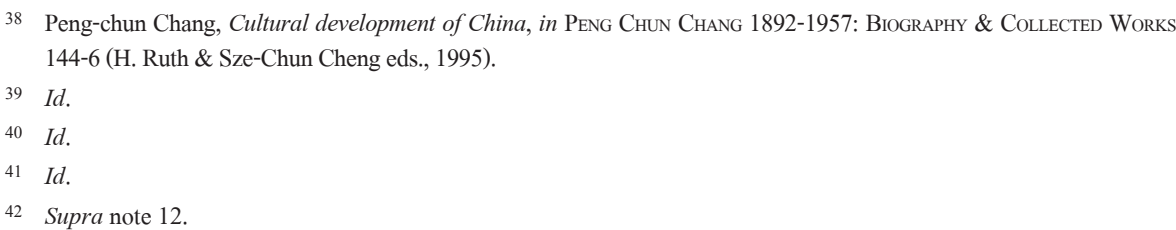


Table 1: Human Dignity in Chang's Concept for Drafting the UDHR ${ }^{43}$

\begin{tabular}{|c|c|c|c|}
\hline No & Meeting & Date & P. C. Chang's Main Ideas \\
\hline 1 & $\begin{array}{l}\text { The 7th meeting of } \\
\text { the 1st session of the } \\
\text { UN Commission on } \\
\text { Human Rights }\end{array}$ & $\begin{array}{c}\text { Jan. 31, } \\
1947\end{array}$ & $\begin{array}{l}\text { "A standard should be established with a view to } \\
\text { elevating the concept of man' dignity.,"4 } \\
\text { "P. C. Chang urged the Commission to bear in } \\
\text { mind the historical background of human rights, } \\
\text { particularly the emphasis placed on human values } \\
\text { by the l6th century thinkers." }\end{array}$ \\
\hline 2 & $\begin{array}{l}\text { The 13th meeting of } \\
\text { the 1st session of the } \\
\text { UN Commission on } \\
\text { Human Rights }\end{array}$ & $\begin{array}{c}\text { Feb. 4, } \\
1947\end{array}$ & $\begin{array}{l}\text { "Dr. CHANG (China) considered that the principle } \\
\text { of equality should be examined, bearing in mind the } \\
\text { concept of human dignity." }\end{array}$ \\
\hline 3 & $\begin{array}{l}\text { The 8th meeting of } \\
\text { the 1st session of the } \\
\text { Drafting Committee }\end{array}$ & $\begin{array}{c}\text { June 17, } \\
1947\end{array}$ & $\begin{array}{l}\text { "Dr. CHANG suggested that the word 'dignity' be } \\
\text { used instead of 'life' so that the first sentence would } \\
\text { read: There shall be respect for human dignity.",47 }\end{array}$ \\
\hline 4 & $\begin{array}{l}\text { The 13th meeting of } \\
\text { the 1st session of the } \\
\text { Drafting Committee }\end{array}$ & $\begin{array}{c}\text { June 20, } \\
1947\end{array}$ & $\begin{array}{l}\text { He suggested that Article } 1 \text { should read as it stands: } \\
\text { "All men are brothers. Being endowed with reason } \\
\text { and conscience, members of one family, they are free } \\
\text { and possess equal dignity and rights." }\end{array}$ \\
\hline 5 & $\begin{array}{l}\text { The 17th meeting of } \\
\text { the 1st session of the } \\
\text { Drafting Committee }\end{array}$ & $\begin{array}{c}\text { June 24, } \\
1947\end{array}$ & $\begin{array}{l}\text { P. C. Chang's suggestion was adopted. } \\
\text { Article } 11 \text { then read: "Slavery, which is inconsistent } \\
\text { with the dignity of man, is prohibited in all its } \\
\text { forms." }\end{array}$ \\
\hline
\end{tabular}

Chang discussed 'human dignity' five times at the meetings of the UN Commission on Human Rights and the Drafting Committee. He mentioned the concept of human dignity and human value firstly at the seventh meeting of the first session of the UN Commission on Human Rights. Secondly, at the 13th meeting of the first session of the commission. Thirdly, at the 8th meeting of the first session of the Drafting Committee, where he suggested to replace the term "respect for human life" by "respect for human dignity." Fourthly, he used this concept of human dignity at the

\footnotetext{
43 Compiled by the author.

44 U.N. Doc. E/CN.4/SR.7, at 4.

45 Id.

46 U.N. Doc. E/CN.4/SR13, at 3-4.

47 U.N. Doc. E/CN.4/AC.1/SR.8, at 3.

48 U.N. Doc. E/CN.4/AC.1/SR.13, at 5.

49 U.N. Doc. E/CN.4/AC.1/SR.17, at 14.

50 Supra note 47 , at 3.
} 
13th meeting of the first session of the Drafting Committee. At this meeting he said: "All men are brothers. Being endowed with reason and conscience, members of one family, they are free and possess equal dignity and rights. ${ }^{, 51}$ Finally, he mentioned human dignity at the 17th meeting of the first session of the Drafting Committee. All this course shows that he always bore in mind the concept of human values and dignity in drafting different articles importantly.

\section{3. 'Indignity' Used in China's Proposal Draft of the UDHR}

On May 3, 1948, the Chinese delegation submitted its proposal draft of the UDHR. This was the shortest draft, containing 10 articles as follows: ${ }^{.2}$

Table 2: Draft International Declaration on Human Rights ${ }^{53}$

\begin{tabular}{|c|c|}
\hline Article & Content \\
\hline I & Every person has the right to life. \\
\hline II & $\begin{array}{l}\text { Every person has the right to freedom of conscience and belief, to freedom } \\
\text { of assembly and of association, and to freedom of information, speech and } \\
\text { expression. }\end{array}$ \\
\hline III & $\begin{array}{l}\text { Every person has the right to a decent living; to work and leisure, to health, } \\
\text { education, economic and social security. }\end{array}$ \\
\hline IV & $\begin{array}{l}\text { Every person has the right to take part in the affairs of his government } \\
\text { directly or through his representatives. }\end{array}$ \\
\hline $\mathrm{V}$ & Every person has the right to equal protection under law. \\
\hline VI & Every person has the right to seek asylum from persecution. \\
\hline VII & $\begin{array}{l}\text { No person shall be subjected to unreasonable interference with his privacy, } \\
\text { family, home, correspondence or reputation. }\end{array}$ \\
\hline VIII & No person shall be subjected to arbitrary arrest or detention. \\
\hline IX & $\begin{array}{l}\text { No person shall be held in slavery or involuntary servitude or be subjected } \\
\text { to torture or to cruel or inhuman punishment or indignity. }\end{array}$ \\
\hline $\mathrm{x}$ & $\begin{array}{l}\text { Every person is entitled to the human rights and fundamental freedoms } \\
\text { set forth in this declaration without distinction as to race, sex, language or } \\
\text { religion. The exercise of these rights requires recognition of the rights of } \\
\text { others and the just requirements of the community in which he resides. }\end{array}$ \\
\hline
\end{tabular}

$51 \quad$ Supra note 48.

52 U.N. Doc. E/CN.4/AC.1/18; U.N. Doc. E/CN.4/95, annex A, at 14-5.

53 Submitted by the Chinese Delegation on May 3, 1948. 
The text of the Chinese delegation's draft has several characteristics. First, the wording of each sentence begins with 'every person' or 'no person,' which reflects the human rights principle of universality. Also, the subjects of rights extend to everyone, everywhere, without any distinction as to race, sex, language or religion. In other words, the rights proclaimed by the Declaration belong to all members of human society. Here, the universal principle of human rights is applied to the design of every article.

Second, the two fundamental principles - 'freedom' and 'equality' - of human rights are fully embodied in the text of the Chinese delegation's draft. The word, 'rights' is the most frequently used in providing basic rights. However, the whole Chinese draft embodies the two core concepts of 'freedom' and 'equality,' including "freedom of conscience and belief, freedom of assembly and of association, and freedom of information, speech and expression" and "the right to equal protection under law." Even without using these two terms directly, each article embodies the spirit of freedom and equality.

Third, in particular, in such a simple and concise proposal for a draft declaration, the wording used is 'indignity,' which reflects the Chinese representative's precise grasp of human dignity and includes acts contrary to human dignity (indignity) in the prohibited clauses, thereby making the proposed draft declaration much more effectively embody the respect for human dignity and demonstrate the value and significance of human dignity. According to Chang's speech at the plenary session of the General Assembly, his emphasis on human dignity, freedom and equality, the principle of universal application and the concept of non-Western human rights being included in the UDHR have been reflected.

In addition, it is impossible to exercise rights without any limit because rights should be achieved without infringing on the same rights of others. This requires that the subjects of the rights should assume some obligations, but once the law is violated, the violator should be punished appropriately.

\section{Conclusion}

The UDHR is a milestone for the international protection of human rights. It is consider the greatest achievement of human beings in the 20th century. As the main drafter, P. C. Chang made outstanding contributions to the formulation of the UDHR. Professor Mary Glendon of Harvard University called P. C. Chang, Eleanor 
Roosevelt, René Cassin and Charles Malik 'founding parents' of the Declaration. ${ }^{54}$ Chang formed, enriched and perfected his concept of human rights in the years of interdisciplinary social practice, which has both theoretical and practical grounds. It further contains rich connotative meaning. He valued human dignity from the very beginning of the commission, frequently reminding people of it in the drafting process. He viewed human dignity as the source and foundation of human rights. His suggestions and ideas about human dignity were adopted and included in the UDHR.

We can conclude that Chang was using human dignity to convince people to reach a consensus on human rights standards. He had a broad vision, worthy of someone "reaching the top of Mountain Tai." He saw the biggest issues at the height of all human beings. Based on boundless tolerance, flexible doctrine of diplomatic strategies, skills, and especially his loyalty and deep love for traditional Chinese culture and Confucianism, P. C. Chang was able to deal with issues whenever necessary by quoting and comparing the Confucian classics with the theory of Western philosophers. This style became an important feature of his speeches, reflected in his work for drafting the UDHR. His invaluable contribution to the construction of the international human rights protection system is an important part of history. It should be remembered forever.

54 M. Glendon, Introduction, in The Challenge of Human Rights: Charles Malik and the Universal Declaration 2 (H. Malik ed., 2000). 